\title{
Upaya Meningkatkan Hasil Belajar Peserta Didik Pada Materi Barisan dan Deret Aritmetika Melalui Pendekatan Saintifik TPACK
}

\author{
Unay Nurmansyah ${ }^{a}$,Setiana ${ }^{b}$ \\ a SMK PGRI Ciawigebang dan uneynur@gmail.com \\ b Universitas Islam Al-Ihya Kuningan dan nsetiana708@gmail.com \\ uneynur@gmail.comª), nsetiana708@gmail.com ${ }^{\text {b) }}$,
}

$\frac{\text { Article Info }}{\text { Kaywords :, TPACK, hasil }}$
belajar siswa

belajar siswa
The application of scientific-based learning that is able to foster communication, collaboration and innovation in building critical thinking patterns is very much needed today. At SMK PGRI Ciawigebnag, class XI TKRO 4, there are obstacles on how to manage an effective teaching and learning process that can improve student learning outcomes in that class. So it takes a HOTS scientificbased learning approach by prioritizing collaborative, communicative and teaching and learning processes using TPACK (Technological, Pedagogical, Content Knowledge) is a framework (framework) in designing new learning models by combining three main aspects, namely technology, pedagogy and content / material knowledge (ontology). Learning outcomes are abilities that children get from interactions in the learning process. The research method used in solving this problem using a classroom action research model with descriptive analysis. The results of data analysis and discussion can be concluded as follows: 1) Learning using the TPACK Scientific approach assisted by the STAD cooperative method and the PBL model can improve students' understanding of class XI TKRO 4 SMK PGRI Ciawigebang on the material of the Arithmetic sequence and series concepts in solving contextual problems; 2) Learning using the TPACK scientific approach assisted by the STAD cooperative method and the PBL model can improve the learning activities of class XI TKRO 4 students of SMK PGRI Ciawigebang on the Arithmetic sequence and series concept material in solving contextual problems; and 3) The attitudes of class XI TKRO 4 SMK PGRI Ciawigebang towards learning mathematics after learning through the TPACK Scientific approach assisted by the STAD 
cooperative method and the PBL model in the Arithmetic sequence and series concept material in solving contextual problems is very positive.

Kata Kunci: TPACK, hasil belajar siswa

\begin{abstract}
Abstrak
Penerapan pembelajaran yang berbasis saintifik dan mampu menumbuhkan komunikasi, kolaborasi dan inovatif dalam membangun pola pikir yang kritis, sangatlah dibutuhkan pada masa sekarang ini. Di SMK PGRI Ciawigebnag kelas XI TKRO 4, memiliki kendala bagaiamana pengelolaan proses belajar mengajar yang efektif yang mampu meningkatkan hasil belajar peserta didik di kelas tersebut. Sehingga dibutuhkan sebuah pendekatan pembelajaran yang berbasis saintifik HOTS dengan mengutamakan kolaboratif, komunikatif serta proses belajar mengajar yang menggunakan TPACK (Technological, Pedagogical, Content Knowledge) adalah sebuah framework (kerangka kerja) dalam mendesain model pembelajaran baru dengan menggabungkan tiga aspek utama yaitu teknologi, pedagogi dan konten/materi pengetahuan (ontologis). Hasil belajar adalah kemampuan yang diperoleh anak dari suatu interaksi dalam proses pembelajaran. Metode penelitian yang digunakan dalam pemecahan permasalahan ini menggunakan model penelitian tindakan kelas dengan analisis deskriptf. Hasil analisis data dan pembahasan dapat disimpulkan sebagai berikut:1) Pembelajaran dengan menggunakan pendekatan Saintifik TPACK berbantu metode kooperatif tipe STAD dan model PBL dapat meningkatkan pemahaman siswa kelas XI TKRO 4 SMK PGRI Ciawigebang pada materi konsep Barisan dan deret Aritmetika dalam pemecahan masalah kontektual; 2) Pembelajaran dengan menggunakan pendekatan Saintifik TPACK berbantu metode kooperatif tipe STAD dan model PBL dapat meningkatkan aktivitas belajar siswa kelas XI TKRO 4 SMK PGRI Ciawigebang pada materi konsep Barisan dan deret Aritmetika dalam pemecahan masalah kontektual; dan 3) Sikap siswa kelas XI TKRO 4 SMK PGRI Ciawigebang terhadap pembelajaran matematika setelah memperoleh pembelajaran melalui pendekatan Saintifik TPACK berbantu metode kooperatif tipe STAD dan model PBL pada materi konsep Barisan dan deret Aritmetika dalam pemecahan masalah kontektual sangat positif.
\end{abstract}

\section{PENDAHULUAN}

Sering kita melihat peran generasi muda atau peserta didik yang lahir era digital ini tidak terpikir baginya sulit menggunakan teknologi, bahkan dengan teknologi membuat mereka lebih matang dan mandiri 196 dalam hal pemanfaatan teknologi tersebut untuk membantu proses belajarnya. Bahkan peserta didik tahu bagaimana mendidik diri sendiri dan mencari informasi melalui teknologi informasi dan komunikasi.Berdasarkan ini keputusan 
pemerintah melaksanakan pembelajaran di rumah bisa terjadi di setiap satuan pendidikan di saat wabah Covid-19, asalkan teknologi informasi (jaringan internet) terjangkau ke setiap satuan pendidikan.Peserta didik Indonesia sangat akrab dengan teknologi informasi, tidak hanya dalam berinteraksi di media sosial tetapi juga untuk kebutuhan pembelajaran.

Dalam hal ini pemerintah sangat tepat mengeluarkan sebuah regulasi menyangkut dengan sistem pembelajaran daring di setiap satuan pendidikan mulai dari tingkat sekolah dasar sampai ke perguruan tinggi, agar bangsa Indonesia tidak ternoda dengan hal-hal yang tidak dibenarkan oleh agama maupun negara agar cepat terhindar dari wabah Covid-19. Dengan perkembangan teknologi informasi dan komunikasi yang begitu cepat dampak yang sangat besar dari sebuah fakta pada lingkungan peserta didik seperti terjadi interaksi belajar-mengajar antar guru dan peserta didik dalam dunia pendidikan saat ini, karena peserta didik lebih dilengkapi teknologi, daripada seorang guru. Di sinilah perlu melibatkan tenaga profesional yang ada di setiap satuan pendidikan untuk meningkatkan kompleksitas proses pembelajaran di satuan pendidikan yang terutama harus melibatkan kepala sekolah sebagai pemimpin manajerial di sekolah. Dengan kemampuan sebagai seorang manajer kepala harus bisa melibatkan guru dan peserta didik, admin atau pun operator sekolah, komite serta orang tua peserta didik, dengan memanfaatkan anggaran sekolah secara efisien dan efektif sesuai dengan kemampuan sekolah masing- masing, demi berlangsungnya sistem pembelajaran daring.

Administrator mempunyai kewajiban untuk mengakses dalam mengelola keseluruhan sistem di antaranya mengelola master data sistem, dan mengelola mengakses seluruh pengguna sistem seperti penyelenggara, guru dan peserta didik dapat mengatur pengelolaan seluruh kelas melalui walikelasnya masingmasing.Sistem pembelajaran seperti di saat wabah Covid-19 ini, sangat sesuai digunakan dalam dunia pendidikan kita karena sesuai dengan keinginan kurikulum 2013 di antaranya sekarang ini dilakukan Pembelajaran Berpusat Pada Peserta didik (Student Centered Learning), sebagaimana yang tertuang dalam Peraturan Menteri Pendidikan dan Kebudayaan (Permendikbud) no. 81A tentang Implementasi Kurikulum 2013.

Permendikbud itu menyebut ada polapola pembelajaran yang perlu diubah. Antara lain pola pembelajaran satu arah (interaksi guru-peserta didik) perlu diubah menjadi pembelajaran interaktif, pola pembelajaran terisolasi menjadi pembelajaran secara jejaring dengan pemanfaatan media teknologi informasi dan komunikasi, dengan pola ini pembelajaran pasif menjadi pembelajaran aktifmencari.Sebuah solusi belajar berbasis teknologi harus bisa menghadirkan sekaligus menguatkan interaksi antara guru dan peserta didik, dengan sistem daring supaya proses pembelajaran tetap berjalan sepeti yang diharapkan oleh masyarakat umum. 
Oleh karena itu, solusi belajar berbasis teknologi pasti harus bisa memberikan solusi tepat dan cepat pada saat peserta didik membutuhkan pembelajaran langsung bisa interaksi antara guru dengan peserta didik secara daring.Dengan harapan bahwa solusi belajar berbasis teknologi informasi bisa sejalan dengan apa yang diajarkan di sekolah dan sesuai dengan kurikulum yang berlaku walaupun dalam kondisi pandemi wabah Covid-19. Harus ada quality control dari tim akademik yang telah dibentuk dalam rangka menanggulangi pembelajaran pada saat mengatasi wabah Covid-19 tentang materi.

Sistem ini harus dilakukan dengan penuh rasa tanggung jawab, karena terkait dengan masa depan generasi anak bangsa. Oleh karena itu guru harus memiliki kemampuan menguasai teknologi informasi dan komunikasi, seperti mendesain konten pembelajaran, mengelola sumber belajar, membangun kemandirian belajar peserta didik, dan berkomunikasi multi-arah.Pola interaksi aktif yang baik harus dibangun, kegiatan belajar bisa dikontrol, kesulitan belajar bisa diselesaikan, hasil belajar bisa terjamin dan berkualitas, dan dapat mengevaluasi pembelajaran, Dengan memanfaatkan media teknologi secara daring dan media lainnya yang sesuai dengan konektivitas internet yang ada di masing-masing satuan pendidikan.

Aktivitas pembelajaran guru dan peserta didik terus berlangsung tanpa ada efek yang sedang dihadapi masyarakat sekarang yaitu penyebaran Covid-
19.Mudah-mudahan dengan sistem seperti ini wabah Covid-19 akan segera lenyap dari lingkungan kehidupan manusia setelah semua komunitas manusia mentaati serta disiplin mengikuti seluruh ketentuan pemerintah dalam masa pencegahan pandemi wabah Covid-19.

Penerapan pembelajaran yang berbasis saintifik dan mampu menumbuhkan komunikasi, kolaborasi dan inovatif dalam membangun pola pikir yang kritis, sangatlah dibutuhkan pada masa sekarang ini. Di SMK PGRI Ciawigebnag kelas XI TKRO 4, memiliki kendala bagaiamana pengelolaan proses belajar mengajar yang efektif yang mampu meningkatkan hasil belajar peserta didik di kelas tersebut. Sehingga dibutuhkan sebuah pendekatan pembelajaran yang berbasis saintifik HOTS dengan mengutamakan kolaboratif, komunikatif serta proses belajar mengajar yang menggunakan TPACK (Technological, Pedagogical, Content Knowledge) adalah sebuah framework (kerangka kerja) dalam mendesain model pembelajaran baru dengan menggabungkan tiga aspek utama yaitu teknologi, pedagogi dan konten/materi pengetahuan (ontologis).

Hasil belajar adalah kemampuan yang diperoleh anak dari suatu interaksi dalam proses pembelajaran. Menurut pendapat W.S. Winkle prestasi belajar adalah nilai yang dfihasilkan oleh murid terhadap pernyataan atau persoalan atau tugas yang diberikan.Hamalik (2003: 154) menyatakan bahwa hasil belajar peserta didik tampai sebagai terjadinya perubahan 
tingkah laku pada peserta didik yang dapat diamati dan diukur dalam bentuk perubahan pengetahuan sikap dan keterampilan.

Menurut Dimyati (1999:3) bahwa "Hasil belajar merupakan suatu interaksi tindakan belajar dan tindakan mengajar. Dari sisi guru, tindakan mengajar diakhiri dengan proses evaluasi hasil belajar, dari sisi peserta didik hasil belajar merupakan puncak proses belajar". Prestasi belajar merupakan penilaian terhadap tingkat keberhasilan belajar individu mencapai tujuan yang telah ditetapkan. Prestasi belajar mengandung arti perubahan tingkah laku atau perbuatan setelah mengalami interaksi belajar mengajar dalam suatu pendidikan. Menurut Oemar Hamalik (2003: 84) bahwa"Prestasi adalah perubahan tingkah laku yang diharapkan pada murid setelah dilakukan proses belajar mengajar".

Sedangkan menurut Moh. Surya (dalam Arofah Eulis, 2006: 16) menyatakan bahwa "Prestasi belajar merupakan seluruh kecakapan yang dicapai melalui proses belajar di sekolah yang dinyatakan dengan nilai-nilai prestasi belajar berdasarkan hasil test prestasi belajar". Syamsudin (1997: 43) mengemukakan "Hasil belajar adalah kecakapan nyata atau actual, yang menujukan aspek kecakapan yang segera didemonstrasikan dan diuji sekarang juga karena merupakan hasil usaha atau belajar yang bersangkutan dengan cara bahan dalam hal tersebut dijalani".

Proses pembelajaran sebagai suatu proses mendukung tiga unsur yang dapat dibedakan, yakni tujuan pengajaran (instruksional), pengalaman (proses) belajar mengajar, dan hasil belajar. Dalam proses pembelajarn, hasil belajar peserta didik harus tampak dalam tujuan pengajaran (instruksional) sebab tujuan itulah yang akan dicapai dalam proses pembelajaran.

Hasil belajar memiliki tujuan tertentu sebagai mana yang dikemukakan oleh Hamalik (2003: 160) yaitu : 1) Memberikan informasi tentang kemajuan peserta didik dalam upaya mencapai tujuan-tujuan belajar melalui berbagai kegiatan; 2) Memberikan informasi yang dapat digunakan untuk membina kegiatan-kegiatan belajar peserta didik lebih lanjut.; 3) Memberikan informasi yang dapat digunakan untuk mengetahui kemampuan peserta didik, memberiikan informasi sebagai dasar untuk mendorong motivasi belajar peserta didik dengan cara mengenal kemajuan sendiri dan merangsang untuk melakukan upaya perbaikan; dan 4) Memberikan informasi yang tepat untuk membimbing peserta didik memilih sekolah atau jabatan yang sesuai dengan kecakapan, minat, dan bakat.

Proses pembelajaran itu pada dasarnya merupakan suatu yang kompleks, sehingga agar proses dan hasil belajar optimal, maka faktor-faktor dalam prose pembelajaran perlu diatur, dkontrol sebaikbaiknya. Faktor-faktor yang mempengaruhi keberhasilan belajar peserta didik yang berasal dari diri sendiri (raw input) menurut Ruseffendi (1991: 9) yaitu Kecerdasan peserta didik, Kesiapan peserta didik, Bakat Peserta didik, Kemampuan peserta didik dan Minat peserta didik. Faktor-faktor yang berasal dari luar (environmental input) meliputi Model penyajian materi pelajaran, Pribadi dan sikap guru, Suasana 
pengajaran, Kompetensi guru, dan Kondisi masyarakat

Technological Pedagogical Content Knowledge (TPACK) adalah suatu kerangka kerja yang mengidentifikasi pengetahuan, guru perlu mengajar secara efektif dengan kerangka teknologi. Menurut Mishra, et al (2016: 2) TPACK adalah suatu kerangka kerja untuk memahami dan menggambarkan jenis pengetahuan yang dibutuhkan oleh seorang guru untuk mengefektifkan praktek pedagogi dan pemahaman konsep dengan mengintegrasikan sebuah teknologi di lingkungan pembelajaran. Konsep dasar hadirnya TPACK adalah Sebagai berikut: TPACK diperkenalkan pertama kali oleh Mishra dan Koehler pada tahun 2006. Mereka mendiskusikan TPACK sebagai kerangka kerja guru/pendesain dalam mengintegrasikan teknologi dalam pembelajaran. Konsep TPACK muncul dalam teknologi pembelajaran didasarkan pada model pedagogy content knowledge (PCK) yang dipelopori oleh Shulman.

Konsep dasar TPACK lebih menekankan hubungan antara materi pelajaran, teknologi dan pedagogi (Harris J., Mishra, P dan Koehler, M, 2009). Interaksi antara tiga komponen tersebut memiliki kekuatan dan daya tarik untuk menumbuhkan pembelajaran aktif yang terfokus pada peserta didik. Hal ini dapat juga dimaknai sebagai bentuk pergeseran pembelajaran yang semula terpusat pada guru bergeser kepada peserta didik. TPACK menekankan hubungan-hubungan antara teknologi, isi kurikulum dan pendekatan pedagogi yang berinteraksi satu sama lain.

Dalam skema TPACK terdapat hubungan antar komponen penyusun, saling beririsan antara materi $(C)$. pedagogi $(P)$ dan teknologi $(T)$ yang berpengaruh dalam konteks pembelajaran.

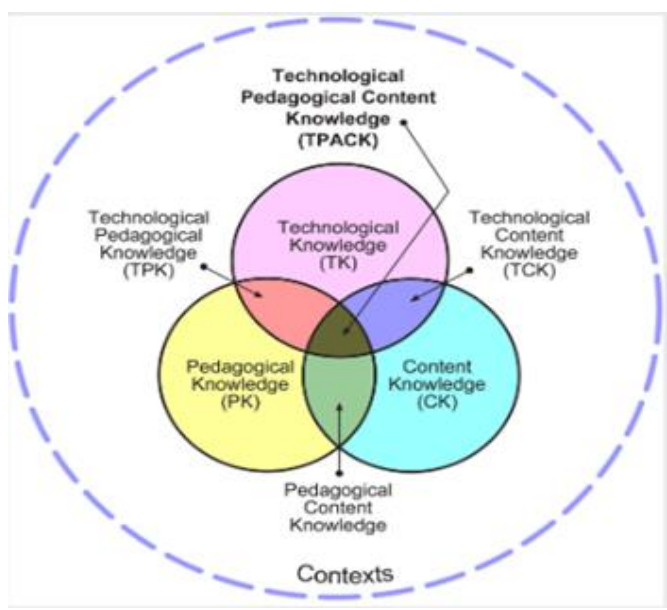

Gambar 2.1 Konsep TPACK

(diadopsi dari Koehler \& Mishra, 2008)

Menurut Stoilescu (2015: 542-543) penggunaan Technological

Pedagogical Content Knowledge (TPACK) dalam praktik dan penelitian pembelajaran memiliki beberapa kelebihan penting, antara lain: 1) Technological Pedagogical Content Knowledge (TPACK) menunjukkan konsistensi dalam pengintegrasian penggunaan teknologi ke dalam konteks yang berbeda; 2) Dengan eksplorasi integrasi TIK di ruang kelas dengan menekankan keterkaitan antara teknologi, 
pedagogi dan konten, kerangka kerja ini memiliki fondasi teoretis yang cukup mapan; dan 3) Dengan terus menyadari tiga aspek utama (teknologi, konten, pedagogis) kegiatan di kelas dapat dilacak dan dianalisis.

Menurut Koehler, Hall, Bouck,\& Wolf (2011) meskipun memiliki beberapa kelebihan, TPACK juga memiliki dua tantangan antra lain: 1) Teknologi baru sering menciptakan peluang baru yang dapat merepresentasikan konten dan pedagogi yang tidak ada sebelumnya; dan 2) Kebanyakan teknologi yang digunakan guru, biasanya tidak dirancang untuk tujuan pendidikan misalnya digunakan untuk perkantoran, bisnis dan lain-lain.

Salah satu materi yang dipelajari dalam matematika SMK adalah barisan dan deret aritmatika. Pengertian Barisan aritmatika adalah baris yang nilai setiap sukunya didapatkan dari suku sebelumnya melalui

penjumlahan atau pengurangan dengan suatu bilangan. Selisih atau beda antara nilai suku-suku yang berdekatan selalu sama yaitu $b$. Nilai suku pertama dilambangkan dengan $a$.

Berdasarkan uraian latar belakang masalah di atas, maka penulis mengadakan Penelitian Tindakan Kelas dengan judul: “Upaya Meningkatkan Hasil Belajar Peserta Didik Pada Materi Barisan dan Deret Aritmetika Melalui Pendekatan Saintifik TPACK(PTK Pada Peserta Didik Kelas XI TKRO 4 SMK PGRI Ciawigebang Tahun Pelajaran 2020/2021)"

\section{METODE}

Metode penelitian yang digunakan dalam pemecahan permasalahan ini menggunakan model penelitian tindakan kelas dengan analisis deskriptf. Penelitian tindakan kelas adalah suatu bentuk penelitian yang bersifat reaktif dengan melakukan tindakan -tindakan tertentu agar dapat memperbaiki atau meningkatkan praktek-praktek pembelajaran di kelas secara lebih professional.

Muslihudin (2009 : 5) Classromm Action Research adalah action research yang dilaksanakan oleh guru di dalam kelas. Action research pada hakikatnya merupakan rangkaian " riset - tindakan - riset - tindakan ,...." Yang dilakukan secara siklik, dalam rangka memecahkan masalah samapai masalah itu terpecahkan. Tujuan penelitian tindakan kelas ini adalah untuk memperbaiki dan meningkatkan layanana professional guru dalam menangani proses belajar mengajar agar tujuan pembelajaran dapat tercapai. Menurut Brong (dalam Suyanto, 1997:8) Penelitian tindakan tujuannnya ialah pengembangan keterampilan guru berdasarkan pada persoalan-persoalan pembelajaran yang dihadapi oleh guru di dalam kelas dan bukannya tujuan untuk pencapaian pengetahuan umum dalam bidang Pendidikan. 


\section{HASIL DAN PEMBAHASAN}

Setelah dilakukan pembelajaran dengan pendekatan Saintifik TPACK menggunakan metode cooperative learning STAD pada materi Barisan dan deret Aritmetika dalam pemecahan masalah di kelas XI TKRO 4 SMK PGRI Ciawigebang Kuningan didapat prosentase hasil belajar dan aktivitas sebagai berikut :

Tabel 4.1 Persentase Hasil Belajar Siswa yang Memperoleh nilai $\geq 70$

\begin{tabular}{|c|c|c|}
\hline Siklus Ke & $\begin{array}{c}\text { Jumlah } \\
\text { siswa } \\
\text { yang } \\
\text { tuntas }\end{array}$ & Persentase \\
\hline $\begin{array}{c}\text { Hasil Pra } \\
\text { Penelitian }\end{array}$ & 18 & $60,00 \%$ \\
\hline I & 20 & $66,67 \%$ \\
\hline II & 26 & $86,67 \%$ \\
\hline
\end{tabular}

Gambar 4.1 Rekapitulasi Ketumtasan Belajar

Table 4.2 Rata-rata Persentase Hasil

\begin{tabular}{|c|c|c|c|}
\hline \multicolumn{2}{|c|}{ Aktivitas } & elajar Siswa & \\
\hline $\begin{array}{c}\text { Siklus } \\
\mathrm{Ke}\end{array}$ & $\begin{array}{l}\text { Rata- } \\
\text { rata }\end{array}$ & Persentase & Kriteria \\
\hline I & 2,25 & $57,5 \%$ & $\begin{array}{l}\text { Cukup } \\
\text { Baik }\end{array}$ \\
\hline II & 2,95 & $73,75 \%$ & Baik \\
\hline
\end{tabular}
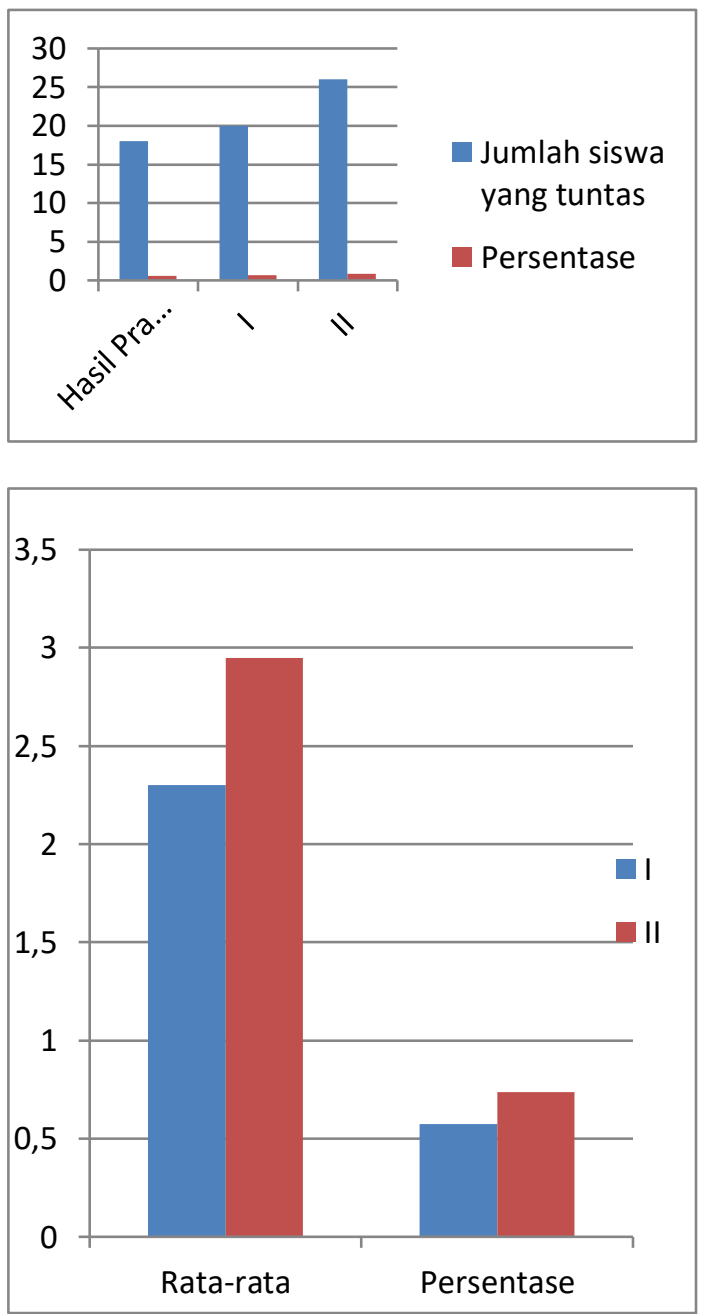


\section{Siklus I}

\section{a. Perencanaan}

Peneliti menyusun rencana kegiatan yang akan dikembangkan dalam kegiatan belajar mengajar,menyusun lembar observasi aktivitas guru dan siswa, catatan lapangan, serta lembar kerja siswa. Metode dan teknik yang digunakan dalam Barisan dan Deret Aritmetika adalah metode Kooperative Tipe STAD. Adapun fokus pembelajaran yang akan disampaikan pada pertemuan pertama yaitu mengenai cara menyatakan Barisan Aritmetika dan pertemuan kedua yaitu Deret Aritmetika

Evaluasi yang digunakan dalam pembelajaran ini adalah evaluasi proses dan hasil. Evaluasi proses dilakukan selama pembelajaran berlangsung, yaitu respon dan keaktifan siswa di kelas, sedangkan evaluasi akhir dilakukan setiap akhir pembelajaran berupa tes barisan Aritemetika dan tes Deret Aritmetika

\section{b. Pelaksanaan dan Observasi}

Pelaksanaan tindakan dilakukan sesuai dengan Rencana Pelaksanaan Pembelajaran (RPP) yang telah disusun oleh peneliti. Pembelajaran pada pertemuan pertama dilaksanakan pada hari Selasa, 20 Oktober 2020. Guru ditemani oleh dua orang observer yang dalam hal ini observernya adalah guru mata pelajaran matematika SMK PGRI Ciawigebang yaitu Bapak Ramdhan, S.Pd dan Ibu Eva Oktaviani,S.Pd. Peran observer di sini adalah mengamati aktivitas guru dan siswa selama proses pembelajaran berlangsung dalam g-meet, serta menuliskannya pada format lembar observasi dan catatan lapangan yang telah disediakan.
Fase 1 : Pada awal pembelajaran guru mengucapkan salam dan mengecek kehadiran siswa. Jumlah siswa yang hadir sebanyak 25 orang. Pada pertemuan pertama ini banyak sekali siswa belum paham dan mengerti dengan kegiatan pembelajaran yang dilakukan sehingga kegiatan belajar kurang efektif.

Selanjutnya guru mengajukan beberapa pertanyaan yang dapat membuka wawasan siswa tentang materi cara menyajikan Barisan Aritmetika, Kemudian guru memberikan motivasi mengenai materi yang akan dipelajari yaitu tentang cara menyajikan Barisan aritmetika,serta menyampaikan tujuan pembelajaran. Untuk merekonstruksi pemahaman siswa.

Fase 2: Guru memberikan contoh studi kasus melalui tayangan power point lalu meminta siswa mendiskusikan bagiamana menemukan suku pertama (a), mendiskusikan bagaimana cara menemukan selisih antar suku (b), menentukan nilai suku ke - 10 barisan aritmetika, menemukan bagaimana pola umu rumus suku ke-n barisan aritmetika. Para siswa cukup antusias mendiskusikannya untuk menjawab pertanyaan guru sehingga kelas g-meet sedikit gaduh. Namun, hal itu sangat baik, artinya siswa merespon dan termotivasi untuk mengikuti pembelajaran. Selanjutnya guru meminta siswa untuk mengungkapkan cara menemukannya melalui lisan lewat $g$ meet. Beberapa siswa mengangkat tangan untuk menjawab. Guru mempersilakan siswa untuk mengungkapkan dengan cara lisan dan menuliskannya di dalam power point. Pada umumnya para siswa cukup 
mengetahui cara menemukan nilai suku pertama barisan aritmetika dan selisih antar suku barisam aritmetika. Selanjutnya guru meminta siswa untuk membuktikannya untuk suku ke-10 untuk menguji pola yang sudah terangkai dengan baik sebelum siswa menemukan pola umum rumus suku ke-n dan memberikan motivasi lagi kepada siswa untuk menemukan pola rumus suku ke-n. Ketika sedang proses diskusi, siswa cukup serius memperhatikan dan mencatat hal-hal yang penting. Setelah itu, guru melakukan tanya jawab mengenai materi yang telah disampaikan. Kegiatan ini berlangsung selama 3 menit, karena hanya beberapa siswa yang mengajukan pertanyaan. Melihat kondisi ini, guru menganggap bahwa siswa sudah memahami materi yang disampaikan.

Fase 3 : Guru membagi siswa menjadi 5 kelompok sesuai urutan absen. Masingmasing kelompok terdiri atas 6 orang dan guru membagikan LKPD yang dishare lewat WA yang harus didiskusikan dalam kelompok. Lalu, siswa berdiskusi dengan teman sekelompoknya lewat WA membahas soal yang diberikan oleh guru. Dalam tahap ini, setiap orang diberikan kesempatan untuk bertanya serta mengemukakan pendapat/idenya untuk menjawab permasalahan atau soal yang ada dalam LKPD. Diskusi ini dimaksudkan untuk menyelesaikan studi kasus dalam kehidupan sehari-hari (soal HOTS) hal-hal yang belum diketahui dan memungkinkan tiap siswa untuk berdiskusi, mendapatkan masukan dan pengetahuan dari teman sekelompoknya yang lebih paham.
Fase 4 : Ketika proses diskusi berlangsung, siswa sedikit gaduh dan kurang terkondisikan, dikarenakan mereka saling berdiskusi dalam g meet. Lalu, untuk mengatasinya, guru melihat lewat layar $\mathrm{g}$ meet siswa yang paling keras irama suaranya untuk esdikit tidak gaduh dan meminta tiap kelompok untuk melihat aktivitas diskusi mereka. Terdapat beberapa siswa yang aktif berpendapat. Selain itu, guru juga membimbing siswa apabila ada hal yang kurang dipahami. Setelah dilakukan pendekatan, siswa kembali serius berdiskusi dengan teman sekelompoknya. Guru juga memberikan motivasi tambahan jika jawaban soal dituliskan dalam bentuk word maka akan mendapatkan nilai maksimal diatas KKM, sebagai bentuk motivasi dalam mendorong siswa untuk menggunakan teknologi tidak dalam bentuk tulisan tangan lagi. Pada kenyataannya siswa justru mampu menggunakannya, dimana semua jawaban LKPD menggunakan format word.

Fase 5 : guru meminta ketua kelompok mengshare jawaban LKPD lewat WA terlebih dahulu, kemudian setiap ketua kelompok mengshare jawaban LKPD yang diminta. Ada satu kelompok yang telat yaitu kelompok 4 karena terkendala jaringan yang jelek/buruk. Setelah beberapa menit diperiksa, guru mengumumkan bahwa kelompok 1 yang terbaik dan harus presentase di dalam g-meet dan untuk seahring di layar. Selama siswa menjawab soal pada LKPD, guru memperhatikan aktivitas siswa menjawab soal yang ada pada LKPD lewat layar g-meet. Siswa 
terlihat antusias dalam mengerjakan soal mereka.

Fase 6 : Guru mengumumkan kelompok terbaik dan diberikan penghargaan berupa pujian dan tepuk tangan dari semua siswa. Bersama dengan siswa, guru menyimpulkan dan memberikan pengutan materi pelajaran yang telah dipelajari hari ini. Guru memberikan evaluasi berbentuk Quizizz. Yang dishare linksnya lewat WA. Para siswa antusias sekali, hal ini dikarenakan Quizizznya dibuatkan seperti game. Dan akhirnya bel tanda habis pelajaran berbunyi, kemudian guru bersama siswa menyimpulkan materi pelajaran yang telah dipelajari hari ini. Terkhir guru memberikan soal sebagai PR yang akan diperiksa pada pertemuan berikutnya tugas itu dimaksudkan sebagai bahan yang akan mereka pelajari pada pembelajaran berikutnya.

\section{c. Analisis Hasil Belajar Siswa}

\begin{tabular}{|l|}
$\begin{array}{c}\text { Gambar } 4.3 \text { Rekapitulasi } \\
\text { Ketuntasan Siklus I }\end{array}$ \\
Banyak siswa yang Tuntas \\
Persentasen siswa Tuntas \\
Siswa yang belum tuntas \\
Persentase Siswa belum tuntas \\
$14 \begin{array}{l}16 \\
46,68 \% 33 \%\end{array}$ \\
2
\end{tabular}

Dari hasil tes uji siklus I yang dilaksanakan pada hari selasa tanggal 20 Oktober 2020 yang diikuti oleh 30 siswa kelas XI TKRO 4 SMK PGRI Ciawigebang didapat 14 orang siswa mendapat nilai $\geq 70$ atau $46,67 \%$ siswa tuntas dan 16 orang siswa mendapat nilai dibawah 70 atau 53,33 $\%$ siswa tidak tuntas belajar. Berdasarkan indicator keberhasilan penelitian siklus I belum berhasil karena kriteria keberhasilan penelitiannya $46,67 \%$ siswa mendapat nilai $\geq 70$.

Dari hasil observasi pada aktivitas belajar siswa ternyata masih banyak hamper semua aktivitas kategorinya kurang baik berdarakan kriteria maka aktivitas belajar siswa pada siklus I belum berhasil.

\section{d. Refleksi}

Refleksi dilakukan setelah peneliti mengidentifikasi data yang diperoleh dari hasil observasi peneliti mitra (observer), catatan lapangan yang dilakukan oleh peneliti mitra dan peneliti selama pemebalajaran siklus pertama berlangsung. Refleksi siklus pertama akan dijadikan perbaikan untuk siklus berikutnya.

Sebagaimana yang diuraikan dalam hasil observasi di atas, bahwa permasalahan yang dialami guru selama pembelajaran pertama ini kurang cermat dalam mengefektifkan waktu, kurang bisa mengkondisikan situasi kelas daring, pemafaatan table pens kurang efektif, dan suara kurang keras. Permasalahan tersebut hampir sesuai dengan hasil catatan lapangan peneliti dan peneliti mitra selama pembelajaran siklus pertama berlangsung.

Untuk mengatasi masalah dan tidak tidak melakukan kesalahan yang sama pada 
siklus II guru harus lebih memperhatikan dalam penggunaan waktu, memperhatikan kondisi kelas, penggunaan papan tulis, serta suara dalam menjelaskan materi. Penelitian selanjutnya akan dilaksanakan senin 26 Oktober 2020 sesuai dengan jam pelajaran matematika di kelas XI TKRO 4 SMK PGRI Ciawigebang.

\section{Siklus II}

\section{a. Perencanaan}

Peneliti menyusun rencana kegiatan yang akan dikembangkan dalam kegiatan belajar mengajar,menyusun lembar observasi aktivitas guru dan siswa, catatan lapangan, serta lembar kerja siswa. Melalui pendekatan Saintifik TPACK metode kooperative tipe STAD berbantu model PBL pada materi Deret Aritmetika. Adapun fokus pembelajaran yang akan disampaikan pada pertemuan pertama yaitu menemukan suku pertama pada deret aritmetika, selisih / antar suku pada deret aritmetika, menentukan jumlah 8 suku pertama dan menemukan pola umum rumus deret aritmetika.

Evaluasi yang digunakan dalam pembelajaran ini adalah evaluasi proses dan hasil. Evaluasi diakhir proses juga dilakukan selama pembelajaran berlangsung, yaitu respon dan keaktifan siswa di kelas, sedangkan evaluasi akhir dilakukan setiap akhir pembelajaran berupa tes uji siklus dengan aplikasi Quizizz yang berbentuk game permainan .

\section{b. Pelaksanaan dan Observasi}

Pembelajaran pada pertemuan kedua dilaksanakan pada hari senin, 26 Oktober 2020. Guru ditemani oleh dua orang observer yang dalam hal ini observernya adalah guru mata pelajaran matematika SMK PGRI Ciawigebang yaitu bapak Ramdhan,S.Pd. dan Ibu Eva Oktaviani, S.Pd. Peran observer di sini adalah mengamati aktivitas guru dan siswa selama proses pembelajaran berlangsung, serta menuliskannya pada format lembar observasi dan catatan lapangan yang telah disediakan.

Fase 1 : Pada awal pembelajaran guru mengucapkan salam dan mempresensi kehadiran siswa. Jumlah siswa yang hadir sebanyak 28 orang dan 2 orang tidak hadir karena sakit. Pada pertemuan kedua ini siswa sudah mulai paham dan mengerti dengan sintak - Sintak kegiatan pembelajaran yang dilakukan sehingga kegiatan belajar berjalan dengan baik. Selanjutnya melalui bantuan power point guru memberikan motivasi mengenai materi yang akan dipelajari yaitu tentang deret aritmetika dengan tujuan pembelajaran ; menemukan suku pertama (a) pada deret Arimetika, menemukan nilai selisih antar suku (b) pada deret aritmetika, menentukan jumlah 8 suku pertama pada deret aritmetika, menemukan pola umum rumus deret aritmetika.

Fase 2 : melalui sharing presentase guru menampilkan masalah kontektual yang ada dalam kehidupan sehari - hari, siswa diminta menemukan suku pertama (a) pada deret Arimetika, menemukan nilai selisih antar suku (b) pada deret aritmetika, menentukan jumlah 8 suku pertama pada deret aritmetika, menemukan pola umum rumus deret aritmetika. Para siswa sudah memahami sintak bagian ini sehingga 
pencarian dalam menemukan suku pertama (a) pada deret Arimetika, menemukan nilai selisih antar suku (b) pada deret aritmetika, menentukan jumlah 8 suku pertama pada deret aritmetika, menemukan pola umum rumus deret aritmetika dapat diselesaikan dengan baik dan disampaikan secara lisan lewat g-meet, sedangkan guru membantu menampilkannya dalam bentuk power point agar dapat dituliskan pada buku tulis masing-masing. Guru memberikan beberapa pertanyaan yang berupa penguatan materi tentang deret aritmetika. Para siswa antusias untuk menjawab pertanyaan guru sehingga kelas meeting sedikit gaduh. Namun, hal itu sangat baik, artinya siswa merespon dan termotivasi untuk mengikuti pembelajaran.

Fase 3 : Guru meminta siswa untuk berkumpul ke dalam kelompok yang sudah dibentuk pada pertemuan pertama. Kemudian guru mengshare LKPD lewat WA, Selanjutnya guru meminta siswa untuk menyelesaikan permasalahan kontektual yang ada dalam LKPD 2 Deret Aritmetika. Pada sintak ini siswa sudah memahami sehingga proses diskusi lebih cepat lagi bahkan sekarang siswa sudah lebih rapih lagi dalam menjawab soal dengan menggunakan word. Lalu, siswa berdiskusi dengan teman sekelompoknya. Dalam tahap ini, setiap orang diberikan kesempatan untuk bertanya serta mengemukakan pendapatnya untuk menjawab permasalahan atau soal yang ada dalam LKPD sesama teman atau kelompok lain lewat chat WA. Diskusi ini dimaksudkan untuk menjawab konsep yang belum dipahami benar dan memungkinkan tiap siswa untuk bertukar fikiran, mendapatkan masukan dan pengetahuan dari teman sekelompoknya yang lebih paham.

Fase 4 : Ketika proses diskusi berlangsung, siswa sangat antusias dan sungguh-sungguh dalam berdiskusi dengan teman sekelompoknya untuk menjawab permasalahan dalam LKPD 2 Deret aritmetika. Lalu, guru mengajukan pertanyaan selesai atau belum ? ada kesulitan atau tidak ? untuk melihat aktivitas diskusi mereka. Terdapat ada beberapa siswa yang aktif dalam kegiatan diskusi. Setelah selesai, setiap perwakilan kelompok mengshare jawaban LKPD nya lewat WA. Di posisi pertama adalah kelompok 3.

Fase 5 : guru meminta ketua kelompok 3 untuk melakukan presentase di dalam g-meet untuk hasil diskusi dan pemikirannya, bebantu oleh gur yang menayangkan hasil jawaban kelompok 3 dan ketua kelompok membacakannya. Setelah selesai, guru meminta seliuruh siswa untuk memberikan oplos meriah kepada kelompok 3. Beberapa siswa antusias mengajukan pertanyaan dan saling menjawab terkait penjelasan diskusi tersebut. Hal ini, sangat baik sekali karena pembelajaran menjadi lebih baik dan lebih hidup lagi

Fase 6: Guru memberikan soal evaluasi melalui quizizz yang berbentuk game. Semua siswa terantusias karena ingin memperoleh rangking ke 1 dalam game.setelah selesai, dilanjutkan penguatan materi tentang kasus tersebut untuk siswa lebih memahami dengan mengajukan beberapa pertanyaan asesment serta 
refleksi terhadap materi yang telah dipelajari, dan guru juga menginformasikan materi yang selanjutnya untuk pertemuan depan, agar siswa bisa mempersiapkannya. Untuk mengakhiri kegitan guru meminta siswa yang terbaik dalam diskusi untuk memimpin do'a penutup pembelajaran daring hari ini.

\section{c. Analisis Hasil Belajar Siswa}

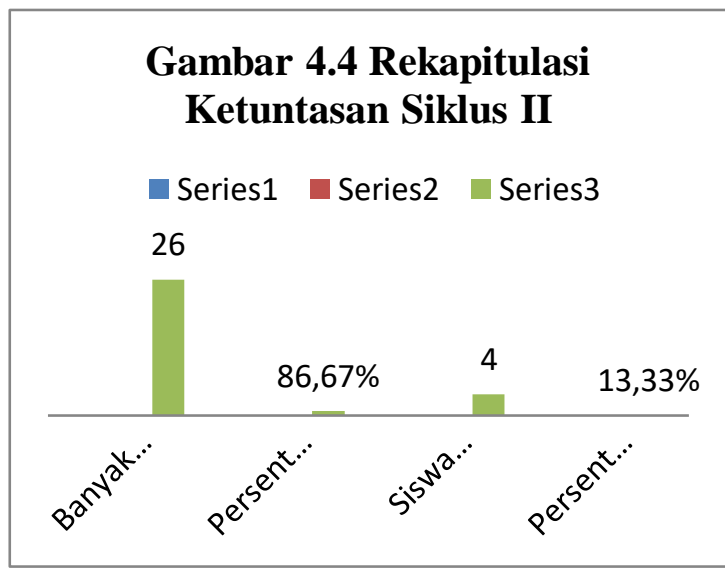

Dari hasil tes uji siklus I yang dilaksanakan pada hari Selasa tanggal 26 Oktober 2020 yang diikuti oleh 30 siswa kelas XI TKRO 4 SMK PGRI Ciawigebang didapat 24 orang siswa mendapat nilai $\geq 70$ atau $86,67 \%$ siswa tuntas dan 6 orang siswa mendapat nilai dibawah 70 atau 13,33\% siswa tidak tuntas belajar. Berdasarkan indicator keberhasilan penelitian siklus II sudah berhasil karena kriteria keberhasilan penelitiannya $86,67 \%$ siswa mendapat nilai $\geq 70$.
Dari hasil observasi pada aktivitas belajar siswa dibandingkan dengan siklus I ada Peningkatan dengan kriterianya semua indikator berpredikat baik maka dapat di simpulkan aktivitas belajar siswa pada siklus II berhasil.

Sikap siswa sangat baik dan antusias dalam pembelajaran pada Barisan dan Deret Aritmetika dengan menggunakan pendekatan saintifik metode kooperatif tipe STAD berbantu model PBL. Hal ini terlihat dari hasil angket yang teah diberikan dan dijawab oleh siswa pada umumnya setuju. Data hasil angket sebagai berikut :

Dari hasil perhitungan di atas, diperoleh rata-rata persentase respon positif adalah $96 \%$. Berdasarkan Kriteria respon positif termasuk dalam kategori sangat positif karena berada di atas $85 \%$.

\section{d. Refleksi}

Refleksi dilakukan setelah peneliti mengidentifikasi data yang diperoleh dari hasil observasi peneliti mitra (observer), catatan lapangan yang dilakukan oleh peneliti mitra dan peneliti selama pemebalajaran siklus pertama berlangsung. Refleksi siklus pertama akan dijadikan perbaikan untuk siklus berikutnya.

Sebagaimana yang diuraikan dalam hasil observasi di atas, bahwa permasalahan yang dialami guru selama pembelajaran sikus sebelumnya sudah teratasi. Pelaksanaan siklus kedua sudah baik. jadi untuk sikus berikutnya tinggal mempersiapkan seperti pada sikus kedua. Penelitian selesai sampai siklus II. 


\section{B. PEMBAHASAN}

Pembelajaran dengan menggunakan pendekatan saintifik TPACK dengan metode Kooperatif Tipe STAD berbantu PBL, sangat membantu guru dalam menyampaikan materi pelajaran serta menciptakan proses pembelajaran yang melibatkan siswa khusunya dalam memahami materi pelajaran. Siswa kelas XI TKRO 4 SMK PGRI Ciawigebang sangat antusias dalam menerima materi pelajaran. Penelitian penerapan pembelajaran dengan menggunakan pendekatan saintifik TPACK dengan metode Kooperatif Tipe STAD berbantu PBL ini dilaksanakan dalam 2 siklus dan diperoleh hasil yang memuaskan pada akhir siklus.

Siklus pertama belum berjalan dengan baik, karena masih banyak kekurangan dalam proses pembelajaran. Kekurangan tersebut terletak pada kinerja guru dalam pengembangan dan pengelolaan waktu serta penggunaan papan tulis masih belum baik dan efektif. Selain itu siswa masih terlihat kebingunagan dengan kegiatan pembelajaran yang dilaksanakan karena mereka masih belum kenal dan paham dengan kegiatan pembelajaran yang dilaksanakan. Akan tetapi, kondisi tersebut dapat segera diatasi sehingga proses belajar siswa pada pertemuan kedua siklus satu berjalan dengan lancar.

Hasil belajar yang dicapai pada siklus I yang dilaksanakan pada hari Selasa tanggal 20 Januari 2020 didapat hasil belajar siswa pada siklus I dari 30 siswa yang mengikuti Uji siklus I ada 14 orang (46,67\%) siswa memperoleh nilai $\geq 70$. Berdasarkan indikator keberhasilan penelitian pada siklus
I belum tercapai dimana indicator keberhasilan penelitian $85 \%$ siswa memperoleh nilai $\geq 70$. Dilihat dari aktivitas siswa belajar siswa masik berkategori kurang baik.

Pada siklus II kegiatan aktivitas belajar siswa semakin meningkat karena siswa sudah terbiasa dengan kegiatan pembelajaran dan sudah mencapai kategori baik. Hal itu berpengaruh banyak terhadap hasil belajar siswa dalam menjawab soalsoal yang diberikan oleh guru. Sehingga pada tes uji siklus II yang dilaksanakan pada hari senin tanggal 26 oktober 2020 dari 30 siswa yang mengikuti tes uji siklus II ada 26 orang $(86,67 \%)$ siswa memperoleh nilai $\geq$ 70. Berdasarkan indikator keberhasilan penelitian pada siklus II sudah tercapai dimana indikator keberhasilan penelitian 85 $\%$ siswa memperoleh nilai $\geq 70$. Dengan demikian pelaksanaaan pembelajaran dengan menggunakan pendekatan saintifik TPACK berbantu metode kooperatif tipe STAD dan model PBL dapat meningkatkan hasil belajar matematika kelas XI TKRO 4 SMK PGRI Ciawigebang tahun pelajaran 2020/2021 pada materi konsep Barisan dan Deret Aritmetika dalam pemecahan masalah kontektual.

\section{PENUTUP}

\section{Simpulan}

Berdasarkan hasil analisis data dan pembahasan dapat disimpulkan sebagai berikut:1)Pembelajaran dengan menggunakan pendekatan Saintifik TPACK berbantu metode kooperatif tipe STAD dan model PBL dapat meningkatkan pemahaman siswa kelas XI TKRO 4 SMK 
PGRI Ciawigebang pada materi konsep Barisan dan deret Aritmetika dalam pemecahan masalah kontektual; 2) Pembelajaran dengan menggunakan pendekatan Saintifik TPACK berbantu metode kooperatif tipe STAD dan model PBL dapat meningkatkan aktivitas belajar siswa kelas XI TKRO 4 SMK PGRI Ciawigebang pada materi konsep Barisan dan deret Aritmetika dalam pemecahan masalah kontektual; dan 3) Sikap siswa kelas XI TKRO 4 SMK PGRI Ciawigebang terhadap pembelajaran matematika setelah memperoleh pembelajaran melalui pendekatan Saintifik TPACK berbantu metode kooperatif tipe STAD dan model PBL pada materi konsep Barisan dan deret Aritmetika dalam pemecahan masalah kontektual sangat positif.

\section{Saran}

Agar pembelajaran dengan menggunakan pendekatan Saintifik TPACK berbantu metode kooperatif tipe STAD dan model PBL dapat berlangsung dengan baik perlu diperhatikan hal-hal sebagai berikut :1) Para pengajar diharapkan selalu berusaha memperbaiki pendekatan pembelajaran, model, metode dan teknik pengajaran untuk meningkatkan mutu pendidikan, baik meningkatkan kemampuan siswa maupun kemampuan mengajar guru; 2) Penelitian pembelajaran konsep Barisan dan Deret Aritmetika dalam pemecahan masalah kontektual dengan menggunakan pendekatan Saintifik TPACK berbantu metode kooperatif tipe STAD dan model PBL baru permulaan, sehingga penelitian serupa yang lebih komprehensif masih perlu dilakukan untuk memperoleh hasil yang lebih memuaskan; 3) Pendekatan Saintifik TPACK berbantu metode kooperatif tipe STAD dan model PBL terbukti berhasil dalam meningkatkan kemampuan siswa pada materi konsep Barisan dan Deret Aritmetika dalam pemecahan masalah kontektual. Oleh karena itu, peneliti merekomendasikan Pendekatan Saintifik TPACK berbantu metode kooperatif tipe STAD dan model PBL untuk dapat diterapkan dalam pembelajaran matematika yang lain; dan 4) Penelitian tindakan kelas dipandang tepat untuk memperbaiki kinerja para pengajar dan proses pembelajaran sehingga hasil belajar siswa pun dapat dioptimalkan. Maka dari itu, peneliti merekomendasikan PTK sebagai salah satu upaya peningkatan kualitas pendidikan di sekolah

\section{DAFTAR PUSTAKA}

Arikunto,S. (2006). Prosedur Penelitian. Jakarta: Rineka Cipta.

Arofah, E. (2006). Penerapan Pendekatan SAVI Pada Pembelajaran Persegi Panjang dan Persegi Dalam Upaya Meningkatkan Hasil Belajar Siswa.Skripsi . Bandung : Universitas Islam Nusantara tidak di terbitkan.

Ayoib, C. A., \& Nosakhare, P. O. (2015). Directors culture and environmental disclosure practice of companies in Malaysia. International Journal of Business Technopreneurship, 5(1), 99-114. 
Dimyati.(2006). Belajar dan Pembelajaran. Jakarta.Rineka Cipta.

Hamalik, O. (2003). Proses Belajar Mengajar. Jakarta. Bumi Aksara.

http://jurnalbidandiah.blogspot.co.id/2012/0 4/model-pembelajaran-kepalabernomor.html

https://wahyutrilestari.com/tpackmateri.html Ibrahim. (2008). Strategi Pembelajaran Matematika. Yogyakarta : UIN Sunan Kalijaga.

Madya, Suwarsih. 2006. Teori dan Praktik Penelitian Tindakan. Bandung: Alfabeta.

Muslihudin . (2009). Kiat sukses Melakukan Penelitian Tindakan Kelas. Bandung. Rizqi Press.

Muthiasari, Sri.(2019) Peningkatan pemahaman konsep barisan dan deret Aritmetika dengan model pembelajaran mind mapping (PTK pembelajaran matematika siswa kelas $X \quad$ SMK Gajah Mungkur Sidoharjosemester gasal tahun 2018/2019). Surakarta . Skripsi

Rohmawati, L. (2019). Pengaruh Pengawas dan Direksi Wanita Terhadap Risiko Bank Dengan Kekuasaan CEO Sebagai Variabel Pemoderasi (Studi Bank Umum Indonesia). Syntax Literate; Jurnal IImiah Indonesia, 4(9), 26-42.

Ruseffendi, E.T. (2006). Pengantar Kepada Membantu Guru mengembangkan kompetensinya dalam pengajaran matematika untuk meningkatkan CBSA. Bandung : Transito.
Sudjana. (2000). Metode dan Teknik Pembelajaran Partisifatif. Bandung.Falah Production.

Wang, Ning Tao, Huang, Yi Shin, Lin, Meng Hsien, Huang, Bryan, Perng, Chin Lin, \& Lin, Han Chieh. (2016). Chronic hepatitis B infection and risk of antituberculosis drug-induced liver injury: Systematic review and metaanalysis. Journal of the Chinese Medical Association, 79(7), 368-374

Winkell, W.S. (1986). Fsikologi dan Evaluasi Belajar. Jakarta.Gramedia. 